\title{
Contemporary Challenges for the Academic
}

\author{
Carlos Miguel Ferreira ${ }^{1}$, Sandro Serpa ${ }^{2,3}$ \\ ${ }^{1}$ Estoril Higher Institute for Tourism and Hotel Studies, Polytechnic Institute of Castelo Branco, Interdisciplinary Centre \\ of Social Sciences - CICS.NOVA,Portugal \\ ${ }^{2}$ University of the Azores, Faculty of Social and Human, Sciences, Department of Sociology, Interdisciplinary Centre of \\ Social Sciences -CICS.UAc/CICS.NOVA.UAc, Portugal \\ ${ }^{3}$ Interdisciplinary Centre for Childhood and Adolescence -NICA - UAc, Ponta Delgada, Portugal \\ Correspondence: Sandro Serpa, University of the Azores, Faculty of Social and Human Sciences, Department of \\ Sociology, Ponta Delgada, Portugal.
}

\author{
Received: September 24, 2018 \\ Accepted: November 21, $2018 \quad$ Online Published: November 22, 2018 \\ doi:10.11114/ijce.v2i1.3786 \\ URL: https://doi.org/10.11114/ijce.v2i1.3786
}

\begin{abstract}
This reflection aims to offer a contribution on some of the main challenges that academics have to face in their professional practice. To this end, we will analyse two components of the academic's activity - teaching and research -, as well as the potentialities of their association, mobilising in this reflection the authors' academic experience, especially in the disciplinary field of Sociology. It is concluded that, despite the academic's high expertise, there are several instigations that lead us to consider the need for a permanent update, so as to encourage, in an intentional and successful way, his/her action.
\end{abstract}

Keywords: academic, teaching, learning, research, higher education

\section{Introduction}

What does the academic do? He/she favours a positioning, in his disciplinary field, that emphasises the articulation, in an interdependent way, of the science, training and profession components. In the science component, sciences are acknowledged, to a greater or lesser extent, as scientific disciplines that envisage social reality in their own way, elaborating plural theoretical topics, formulating research problems in the context of these topics and building sets of principles, theories, methodological strategies and crucial results that serve as a model or guideline for research. In the profession component, the diversity of professional roles and practices, the processes of constitution of social scientists as a professional group, their forms of professional association and the models of professional culture are to be highlighted. In the training models and practices, which are articulated with the science and the profession components, several elements are relevant may can be the object of analysis, such as the structure of programmes and curricular units, the syllabuses of the curricular units, the teachers' qualifications and competencies, and the teaching/learning activities developed (Costa, 2004; Serpa \& Ferreira, 2017).

Being and becoming an academic is a process that takes place in academic institutions, in which different models are intertwined. They are the knowledge model, which corresponds to the Humboldtian idea of university (the «research model»); the professional model, which corresponds to the model of the French grandes écoles (the «training model»), focused mainly on the production of professionals for the State apparatus; and the personality model, following the Oxbridge tradition, of character development through a liberal education (the «personality model») (Magalhães, 2006).

Several authors sustain that knowledge production is changing, shifting from a mode in which the search for knowledge per se frames the process of its production - contextualised by the ideal that academic knowledge contributes to the emancipation of individuals - to a mode of knowledge production that aims at its application (Becher \& Trowler, 2001; Gibbons et al., 1994; Magalhães, 2004). There is a shift from pure and applied research to strategic sciences, where the basic research carried out generates the expectation that the knowledge produced may be the solution to current problems or to problems that may arise in the future (Irvine \& Martin, 1984). While the first knowledge production mode develops around the ethos expressed in the acronym CUDOS (communalism, universalism, disinterestedness, originality and scepticism) (Ziman, 1994), the emerging knowledge production mode values a PLACE (proprietary, local, authoritarian, commissioned and expert) ethos (Sousa, 2010; Ziman, 1994). 
These transformations, which pose several challenges to knowledge as a public good and to academic freedom (Santos, Pereira, \& Lopes, 2016), the increasing universalisation of audiences (Andrade, 2016), the existence of an increasingly digital technology society (Akbar, 2016; Santos \& Serpa, 2017), the reconfiguration of educational policies, systems and educational organisations, as well as the stakeholders' expectations, are some of the aspects that lead to (re)thinking the objectives and the subsequent activity of the academic in the contemporary world, increasing the pressure that falls upon him/her (McCune, 2018).

These reconfigurations, which present numerous challenges to the academic, for example, by questioning "Traditional learning paradigms emphasize discipline-based content and teacher-centered practices" (Andrade, 2016, p. 145), imply a more active (Andrade, 2016; Ferreira \& Serpa, 2017) and engaging teaching, besides the traditional lectures (Akbar, 2016), as well as the promotion of a growing interdisciplinarity, both at the scientific and teaching levels (Serpa, Ferreira, \& Santos, 2017).

This paper offers a contribution regarding some of the main challenges that academics have to face in their profession, framing our positioning in our experience in teaching and research in Sociology. To that end, we will analyse two of the big dimensions of academic activity: research and teaching, although we recognise that the dimension of university governance is also important, as well as service to the community (Bartholomew, 2017; Oertel \& Söll, 2017). As an example, this professional activity of the university teacher is legally summarised, in the Portuguese case, in teaching, research, academic management and service to the community, in a logic of knowledge transfer (Santos et al., 2016).

\section{Activity of the Academic}

Teaching and research are, then, two of the central dimensions of academic activity (Barroso, 2001; Oertel \& Söll, 2017; Williams, Nixon, Hennessy, Mahon, \& Adams, 2016; Wood \& Su, 2017). Indeed, as advocated by Barnett and Bengtsen (2017), "The university is a space for the creation of knowledge ('research') and for its understanding ('teaching and learning')" (p. 1). Although with distinct statutes and valuations, the "unity of teaching and research", the idea that academic teaching is embedded in the research process, shaping the academics' trajectories in higher education (Sousa, 2010). Thus, "the identity of the higher education teacher is, therefore, embodied in the close relationship between teaching and research, which envisages the development of both activities in an articulated way for a better quality training" (Santos et al., 2016, p. 310).

As sustained by Barroso (2001),

[...] what I consider to be one of the main features of university pedagogy: an "author teaching" [...] is a privileged moment when students face the "thought of an author" (of his/her expositions, research and publications) - the academic - and when he/she faces the reaction, the opinion and the experience of his/her "listeners, readers" - the students (p. 88).

\subsection{Teaching}

Teaching is neither an easy nor an immediate activity, although in higher education it is often considered that it is enough that the teacher knows the contents since students already have sufficient ability to foster their own learning (Williams et al., 2016).

In terms of the form, the higher education teacher frequently does not have enough pedagogical preparation (Glaze, 2018, McCune, 2018, Williams et al., 2016), and often relies on a very lecture-like and content-centred teaching (Ferreira, Santos, \& Serpa, 2018).

However, it is already a classic stance to consider teaching simultaneously an art and a science (Arends, 1999; From, 2017). Wood and $\mathrm{Su}$ (2017) demonstrate that even the 'teaching excellence' notion has connotations, implying not only an excellent knowledge of the subject to be taught but also how to teach in higher education as a permanent challenge (Ferreira \& Serpa, 2017).

Regarding the content of what to teach, for instance, in the area that is closest to us - Sociology - Ferreira and Serpa (2017) emphasise, considering the specificities of Sociology, four framing principles that should be fostered in the teaching of Sociology: the need to permanently mobilise sociological imagination (unveiling a preconceived familiarity that can be misleading), be multi-paradigmatic (acknowledging the theoretical and methodological plurality of diverse sociological perspectives), foster self-reflexivity at several levels (critically analyse sociological activity in its possibilities, its limits, its procedures), and, finally, the need to be receptive to a heuristic interdisciplinarity (acknowledging the advantage and the heuristic need to articulate diverse scientific perspectives in the understanding of an object that is always complex, as already referred to by Mauss).

Elements such as the design of the syllabus to be taught, its content and articulation, pedagogical approaches in terms of the teaching style, a clear identification of expected outcomes, a certain flexibility and sensitivity of the academic 
during the course of the class, as well as the relationship that he/she establishes with students, so as to be receptive to students' questions, not forgetting the importance of the teacher-student interactivity, are factors to consider in the training of teachers in higher education (Andrade, 2016; Ferreira \& Serpa, 2017; Williams et al., 2016).

Intentional pedagogical flexibility is critical. For example, Serpa, Ferreira, Santos and Teixeira (2018), when analysing the participatory action research in higher education training, which implies the promotion of active participation of all the intervening elements through research for the resolution of problems in a real context felt in the training process, highlight, along with high potentialities, also clear difficulties of this more active teaching. This is due not only to the specificities of the process itself, but also because it does not correspond to the academics' expectations, as it does not align with the institutionalised culture of most higher education institutions, such as avoiding their own expectations and the traditional roles of students, teachers and even institutional ones, and motivating a different type of work and their (self)control, motivation and assessment.

On the other hand, although higher education institutions are often considered innovation centres (Fortunato, Alter, Frumento, \& Klos, 2015), the digital literacy ability (Santos \& Serpa, 2017; Rivera-Vargas, \& Miño-Puigcercós, 2018) and the ability for the media (Perovic, 2016) becomes essential.

In an increasingly digital academic world,

Pedagogical Digital Competence refers to the ability to consistently apply the attitudes, knowledge and skills required to plan and conduct, and to evaluate and revise on an ongoing basis, ICT-supported teaching, based on theory, current research and proven experience with a view to supporting students' learning in the best possible way (From, 2017, p. 48).

However, these competencies should be used with caution, carefully assessing and weighing their implementation and impact (Akbar, 2016), in an active but flexible way (Ferreira \& Serpa, 2017; Glaze, 2018). The ability of students and even teachers to cope with the potential of digital and technology may be different and it is not a certainty taken for granted (Peres, Moreira, \& Mesquita, 2018; Santos \& Serpa, 2017). It has to be considered by the higher education teacher and fostered in his/her training, whenever necessary.

In short, these are some relevant aspects in the promotion of competencies, such as knowledge of the contents, but also creativity and innovation, such as critical thinking, problem solving, collaboration, communication competencies, innovation, and selection and application competencies (Andrade, 2016; Bellanca \& Brandt, 2010; Hondzel \& Gulliksen, 2015; Santos \& Serpa, 2017).

\subsection{Research}

Scientific research, as systematic knowledge production, is a relatively recent phenomenon. It emerged in the eighteenth century and, in most cases, took place outside universities, which were rigid and controlled organisations, with limited intellectual and innovation abilities (Gellert, 1992; Sousa, 2010).

The increasing valuing and prestige of research enabled the affirmation of the centrality of research in relation to teaching in the academic habitus and led teachers to focus on activities related to research, strengthening, in particular, the process of access to the "academic community", where the $\mathrm{PhD}$ degree enables this goal, through the institutional, professional and epistemological forms (Jackson \& Tinkler, 2000; Sousa, 2010) and the progression in the academic career.

In this "academic community", in which aspects of inequality, hierarchy, and dominance coexist, there is a rating system, which is not always explicit, that shapes fields, objects, theories and methods as "interesting" or "uninteresting" (Bourdieu, 2001, 1997). It also affirms itself as an area of socialisation, of internalisation of values, namely knowledge production, transmission and dissemination, intellectual honesty, integrity and justice towards students, and knowledge and freedom in teaching, learning and research. In the attainment of these values, research, writing, publishing and teaching are central procedures (Austin, 1992; Sousa, 2010).

Academic activity may be understood as scholarship, that is, as a critical and systematic research activity in a field of knowledge and the dissemination of results for peer and public assessment, through the publication of articles, reports, conference presentations or other dissemination outlets. Scholarship has three central features: it should be public, susceptible to critical review and assessment, and accessible for exchange and use by other members of the academic community (Shulman, 1998). Boyer (1990) advocates a broader notion of scholarship, not only linked with research and creative activity, but included in other interdependent roles: discovery, integration, application, and teaching. The discovery scholarship has to do with the traditional mission of pure research activity, of original research, of the search for knowledge for itself, of advancement of specialised knowledge. The integration scholarship seeks to synthesise knowledge in creative ways, bridging fields or disciplines and unravelling new meanings for previously disconnected knowledge. The application or practice scholarship is defined as the application of knowledge to practical problems and 
situations in a rational manner. The teaching scholarship consists of the reflection on the knowledge obtained in research, emphasising the important reciprocal relationship between theory and practice and valuing the knowledge obtained from experience (Boyer, 1990; Filho \& Dias, 2016).

Academic research is intrinsically linked to publication. Furthermore, it also has to respond to social and political demands from the interior and the exterior, such as institutional and community service (Bartholomew, 2017; Oertel \& Söll, 2017; Serpa \& Ferreira, 2017).

The already classic "publish or perish" acknowledges the centrality of research. More than that, it is relevant to materialise this research in scientific publications (Santos et al., 2016), especially articles in scientific journals (Bartholomew, 2017; Ferreira \& Serpa, 2017, 2018; Fonseca, 2017; Oertel \& Söll, 2017). The growing importance of scientific production through scientific productivity expressed in publications (quantity and quality), as well as by citations, has implications as a factor of both institutional and professional legitimacy (Collyer, 2016). Said differently, there are implications, both for professionals and even for the institution where researchers work, for example, in terms of salary and funding for research projects and interdependence with stakeholders (Ceballos, Fangmeyer, Galeano, Juarez, \& Cantu-Ortiz, 2017; Ferreira \& Serpa, 2017). As maintained by Araújo and Silva (2015), at the higher education level, scientific production, as well as knowledge internationalisation, are very important to boost the visibility, legitimacy and even success of both the country and the higher education institution, and even of the academic's career.

Quality and quantity scientific productivity is a very important factor for the status of the academic, such as the impact factor or the number of citations. Ferreira and Serpa $(2017,2018)$ emphasise the need to be aware of the publication process (selection of the type of article, paper writing, choice of the journal to submit them, ...). In this process, knowing, for example, a journal's indexing but also its meaning in the academic world is central for the researcher to make the best choices for his/her future career (Serpa \& Ferreira, 2017).

This is happening at a time of profound change in the industry of scientific articles publishing, with a growing number of journals operating in open access (in a variety of modalities), in a context of increasing political pressure for this type of publication (accessible to all who wish to access it without financial costs) to be the model to implement (Fonseca, 2017; Johnson, Fosci, Chiarelli, Pinfield, \& Jubb, 2017).

The influence of social networks is also not to be neglected (Serpa \& Ferreira, 2017). Social media digital attention, despite its limitations - for example, being prominent in the media does not necessarily mean that the research disclosed has the same proportion of quality - will tend to be, from our standpoint, another factor of valuation of social influence and scrutiny of the common and political citizen. In addition, the need for teachers to express digital literacy in a context of an increasingly digital society is not taken for granted (Santos \& Serpa, 2017).

The development of interdisciplinarity in collaboration in research, although not being easy and generating tensions for going against the instituted professional and scientific institutional status quo, is a highly relevant factor, both in the scientific development and in the increase of opportunities for research funding, either at present or, we believe, for the future (Fonseca, 2017; Santos \& Serpa, 2017; Serpa \& Ferreira, 2017; Serpa et al., 2017).

All of the factors mentioned above, in addition to others, seem necessary for the academic to have the ability to display an author's speech and practice that Barroso (2001) refers to, as previously mentioned.

\section{Conclusion}

This reflection did not directly take into account dimensions such as the connection and impact of the academic's activity on the surrounding community (Ross, 2018), or cultural difficulties, for example, of gender or ethnic, in the academic's activity (Banchefsky \& Park, 2018; Misra, Smith-Doerr, Dasgupta, Weaver, \& Normanly, 2017; Sang, 2018; Ustun, \& Gümüseli, 2017). These are aspects to be developed if we want more just and equitable societies. For instance, in the case of women holding the most prestigious academic function - Rectors - in a specific political and geographical context,

[...] men in increasingly male-dominated academic majors were more likely to endorse Assimilationism - that women should adapt and conform to masculine work norms in order to succeed - and Segregationism - that men and women should pursue traditional social roles and careers. Moreover, they were less likely to endorse Gender Blindness - that attention to gender should be minimized. They were also more likely to agree with the gender-science stereotype that men do better in math and science than women. In contrast, gender imbalance in the major did not influence women's gender ideologies, and women in increasingly male-dominated majors were significantly less likely to endorse the gender-science stereotype (Banchefsky \& Park, 2018, p. 1).

It is concluded that, despite their high expertise, there are several instigations that lead us, on the one hand, to consider 
the need for permanent attention and updating, in order to meet the new needs of an academic world in which the digital is, already, a reality. On the other hand, it is equally critical to consider "the institutional policy context and the value of working creatively with the complexities of emerging academic practices" (McCune, 2018, p. 307).

The answer is not simple, but it is vital that the respect for academic freedom in teaching and research is always present (Butler, 2017; Condon, 2017), as well as critical thinking, but at the same time, sufficiently open and receptive to the exterior (Santos, 2005; Vélot, 2016). Judith Butler (2017) states that "academic freedom implies a right to free inquiry within the academic institution, but also an obligation to preserving the institution as a site where freedom of inquiry can and does take place, free of intervention, and censorship" (p. 1).

We conclude this reflection with the very interesting and pertinent provocation of Rittberger and Richardson (2017), who maintain that, without academic freedom, research will be very limited, running the risk of presenting the following structure mirrored in the articles: "1. No introduction 2. No argument and contribution 3. No analysis 4. No conclusion and avenues for future research 5. No more questions asked" (p. 1).

This study acknowledges that academic freedom is essential and can be beneficial for the academic, for scientific knowledge and, simultaneously, for the society. This study will help the researcher to uncover some critical areas of academic activity, such as digital literacy and institutional policy that frame academic teaching and research.

\section{Acknowledgments}

University of Azores, Interdisciplinary Centre of Social Sciences-CICS.UAc/CICS.NOVA.UAc, UID/SOC/04647/2013, with the financial support of FCT/MEC through national funds and when applicable co-financed by FEDER under the PT2020 Partnership Agreement.

\section{Author Contributions}

All authors had equal contributions to this paper.

\section{Conflicts of Interest}

The authors declare no conflict of interest.

\section{References}

Akbar, M. (2016). Digital technology shaping teaching practices in higher education. Front. in ICT, 3(1). https://doi.org/10.3389/fict.2016.00001

Andrade, M. S. (2016). Curricular elements for learner success-21st century skills. Journal of Education and Training Studies, 4(8), 143-149. https://doi.org/10.11114/jets.v4i8.1743

Araújo, E. R., \& Silva, S. (2015). Temos de fazer um cavalo de Troia. Elementos para compreender a internacionalização da investigação e do ensino superior [We have to make a Trojan horse. Elements for understanding the internationalisation of research and higher education]. Revista Brasileira de Educação, 20(60), 77-98. https://doi.org/10.1590/S1413-24782015206005

Arends, R. I. (1999). Aprender a ensinar [Learning to teach]. Amadora: McGraw-Hill de Portugal.

Austin, A. (1992). Section IV. Faculty and students: Teaching, learning and research, faculty cultures. In B. Clark \& G. Neave (eds.), The encyclopedia of higher education (Vol. 3) (pp. 1614-1623). New York: Pergamon Press.

Banchefsky, S., \& Park, B. (2018). Negative gender ideologies and gender-science stereotypes are more pervasive in male-dominated academic disciplines. Social Sciences, 7(2), 27, 1-21. https://doi.org/10.3390/socsci7020027

Barnett, R., \& Bengtsen, S. (2017). Universities and epistemology: From a fissolution of knowledge to the emergence of a new thinking. Education Sciences, 7(1), 38, 1-12. https://doi.org/10.3390/educsci7010038

Barroso, J. (2001). Teorias das organizações e da administração educacional [Theories of organisations and educational administration]. Lisboa: Universidade de Lisboa, Faculdade de Psicologia e de Ciências da Educação. Unpublished work.

Bartholomew, P. (2017). Beyond research productivity: Matching productivity measures to institutional mission. Journal for the Study of Postsecondary and Tertiary Education, 2, 1-11. https://doi.org/10.28945/3559

Becher, T., \& Trowler, P. (2001). Academic tribes and territories (2nd ed.). Buckingham: The Society for Research into Higher Education \& Open University Press.

Bellanca, J., \& Brandt, R. (Eds.) (2010). 21st century skills: Rethinking how studentes learn. Bloomington: Solution Tree Press.

Bourdieu, P. (1997). Les usages sociaux de la science: Pour une sociologie clinique du champ scientifique [The social 
uses of science: For a clinical sociology of the scientific field]. Versailles: Editions Quæ. https://doi.org/10.3917/quae.bourd.1997.01

Bourdieu, P. (2001). Science de la science et réflexivité: Cours du Collège de France 2000-2001 [Science of science and reflexivity: Course of the Collège de France 2000-2001]. Paris: Éditions Raisons d'Agir (Diffusion: Le Seuil).

Boyer, E. (1990). Scholarship reconsidered: Priorities of the professoriate. Princeton, NJ: Carnegie Foundation for the Advancement of Teaching.

Butler, J. (2017). Academic freedom and the critical task of the university. Globalizations, 14(6), 857-861. https://doi.org/10.1080/14747731.2017.1325168

Ceballos, H. G., Fangmeyer, J., Galeano, N., Juarez, E., \& Cantu-Ortiz, F. J. (2017). Impelling research productivity and impact through collaboration: A scientometric case atudy of knowledge management. Knowledge Management Research \& Practice, 15(3), 346-355. https://doi.org/10.1057/s41275-017-0064-8

Collyer, F. M. (2016). Global patterns in the publishing of academic knowledge: Global North, global South. Current Sociology, 66(1), 56-73. https://doi.org/10.1177/0011392116680020

Condon, B. B. (2017). The chains around academic freedom in teaching-learning. Nursing Science Quarterly, 30(2), 107-111. https://doi.org/10.1177/0894318417693289

Costa, A. F. (2004). Será a sociologia profissionalizável? [Can sociology be professionalised?]. In Sociologia no Ensino Superior: Conteúdos, Práticas Pedagógicas e Investigação [Sociology in Higher Education: Contents, Pedagogical Practices and Research], Proceedings of the Meeting Sociologia no Ensino Superior: Conteúdos, Práticas Pedagógicas e Investigação [Sociology in Higher Education: Contents, Pedagogical Practices and Research], Porto, Portugal, 6.7 December 2002; Gonçalves, C. M., Rodrigues, E., \& Azevedo, N. (Eds.), School of Humanities of the University of Porto: Porto, Portugal, 2004; pp. 35-58.

Ferreira, C. M., \& Serpa, S. (2017). Challenges in the teaching of Sociology in higher education. Contributions to a discussion. Societies - Special Issue Training Models and Practices in Sociology, 7(4), 30, 1-11. https://doi.org/10.3390/soc7040030

Ferreira, C. M., \& Serpa, S. (2018). Publicising the identified peer-reviewer: Legitimacy and quality of the scientific publication. The International Journal of Interdisciplinary Educational Studies, 13(1), 11-17. https://doi.org/10.18848/2327-011X/CGP/v13i01/11-17

Ferreira, C. M., Santos, A. I., \& Serpa, S. (2018). Electronic slideshow presentations in the higher education teaching and learning process. Journal of Education and Training Studies, 6(2), 120-124. https://doi.org/10.11114/jets.v6i2.2818

Filho, J., \& Dias, C. (2016). Profissão acadêmica e scholarship da docência: Novo olhar sobre as múltiplas funções do professor universitário [Academic profession and teaching scholarship: A new look at the multiple functions of a university teacher]. Avaliação, 21(3), 837-857. https://doi.org/10.1590/S1414-40772016000300010

Fonseca, I. L. (2017). Acesso aberto. Modelos, políticas e custos de acesso [Open access. Models, policies and costs of access]. Lisboa: Fundação para a Ciência e Tecnologia.

Fortunato, M. W. P., Alter, T. R., Frumento, P. Z., \& Klos, J. M. (2015). Cultivating a culture of innovative university engagement for local entrepreneurship development in rural and distressed regions. International Journal of Social Science Studies, 3(1), 122-138. https://doi.org/10.11114/ijsss.v3i1.518

From, J. (2017). Pedagogical digital competence - Between values, knowledge and dkills. Higher Education Studies, 7(2), 43-50. https://doi.org/10.5539/hes.v7n2p43

Gellert, C. (1992). Section IV. Faculty and students: Teaching, learning and research. Faculty research. In B. Clark, \& G. Neave (Eds.), The encyclopedia of higher ducation (Vol. 3) (pp. 1634-1641). New York: Pergamon Press.

Gibbons, M., Limoges, C., Nowotny, H., Scwartzman, S., Scott, P., \& Trow, M. (1994). The new production of knowledge. London: Sage Publications.

Glaze, A. L. (2018). Article teaching and learning science in the 21st century: Challenging critical assumptions in post-secondary science. Education Sciences, 8(1), 12, 1-8. https://doi.org/10.3390/educsci8010012

Hondzel, C. D., \& Gulliksen, M. S. (2015). Culture and creativity: Examining variations in divergent thinking within Norwegian and Canadian communities. SAGE Open, 5(4) 1-13. https://doi.org/10.1177/2158244015611448

Irvine, J., \& Martin, B. (1984). Foresight in science: Picking the winners. London: Frances Pinter.

Jackson, C., \& Tinkler, P. (2000). The PhD examination: An exercise in community-building and gatekeeping? In I. 
McNay (Ed.), Higher education and its communities (pp. 38-50). Buckingham: Society for Research into Higher Education/Open Univeristy Press.

Johnson, R., Fosci, M., Chiarelli, A., Pinfield, S., \& Jubb, M. (2017). Towards a competitive and sustainable open access publishing market in Europe. OpenAIRE. doi:10.5281/zenodo.401029

Magalhães, A. (2004). A identidade do ensino superior. Política, conhecimento e educação numa época de transição [The identity of higher education. Politics, knowledge and education in a time of transition]. PhD Thesis, The Netherlands, Twente University.

Magalhães, A. (2006). A identidade do ensino superior: A educação superior e a universidade [The identity of higher education: Higher education and the university]. Revista Lusófona de Educação, 7, 13-40.

McCune, V. (2018). Experienced academics' pedagogical development in higher education: Time, technologies, and conversations. Oxford Review of Education, 44(3), 307-321. https://doi.org/10.1080/03054985.2017.1389712

Misra, J., Smith-Doerr, L., Dasgupta, N., Weaver, G., \& Normanly, J. (2017). Collaboration and gender equity among academic scientists. Social Sciences, 6(1), 25, 1-22. https://doi.org/10.3390/socsci6010025

Oertel, S., \& Söll, M. (2017). Universities between traditional forces and modern demands: The role of imprinting on the missions of German universities. Higher Education., 73(1), 1-18. https://doi.org/10.1007/s10734-016-0013-0

Peres, P., Moreira, F., \& Mesquita, A. (2018). Are really technologies at the fingers of teachers? Results from a higher education institution in Portugal. Journal of Information Systems Engineering \& Management, 3(1), 08. https://doi.org/10.20897/jisem.201808

Perovic, J. (2016). Towards a new, digital communication paradigm. Studies in Media and Communication, 4(1), 99-110. https://doi.org/10.11114/smc.v4i1.1592

Rittberger, B., \& Richardson, J. (2017). What happens when we do not defend academic freedom. Journal of European Public Policy, 24, 1. https://doi.org/10.1080/13501763.2017.1316946

Rivera-Vargas, P., \& Miño-Puigcercós, R. (2018). Young people and virtual communities. New ways of learning and of social participation in the digital society. Páginas de Educación, 11(1), 67. https://doi.org/10.22235/pe.v11i1.1554

Ross, B. (2018). The socially accountable professor in higher education. Journal of Education and Learning, 7(5), 181-187. https://doi.org/10.5539/jel.v7n5p181

Sang, K. J. C. (2018). Gender, ethnicity and feminism: An intersectional analysis of the lived experiences feminist academic women in UK higher education. Journal of Gender Studies, 27(2), 192-206, https://doi.org/10.1080/09589236.2016.1199380

Santos, A. I., \& Serpa, S. (2017). The importance of promoting digital literacy in higher education. International Journal of Social Science Studies, 5(6), 90-93. https://doi.org/10.11114/ijsss.v5i6.2330

Santos, B. S. (2005). A universidade no século XXI: Para uma reforma democrática e emancipatória da universidade [The university in the 21st century: Towards a democratic and emancipatory reform of the university]. Educação, Sociedade \& Culturas, 23, 137-202.

Santos, C. C., Pereira, F., \& Lopes, A. (2016). Efeitos da intensificação do trabalho no ensino superior: Da fragmentação à articulação entre investigação, ensino, gestão académica e transferência de conhecimento. [Effects of work intensification in higher education: From work areas fragmentation to the nexus between teaching, research, leadership and knowledge exchange]. Revista Portuguesa de Educação, 29(1), 295-321. https://doi.org/10.21814/rpe.6820

Schulman, L. (1998). Course anatomy: The dissection and analysis of knowledge through teaching. In P. Hutchings (Ed.), The course portfolio (pp. 13-20). Washington, DC: American Association for Higher Education.

Serpa, S., \& Ferreira, C. M. (2017). Digital social network e legitimacy. The relevance of social visibility of scientific publications in the digital world. In M. Mokrys, \& S. Badura (Eds.), Proceedings of The 5th year of Human and Social Sciences at the Common Conference (HASSACC-2017) (Vol. 5) (pp. 47-51). Zilina, Slovakia, September 25-29. https://doi.org/10.18638/hassacc.2017.5.1.229

Serpa, S., Ferreira, C. M., \& Santos, A. I. (2017). Fostering Interdisciplinarity: Implications for Social Sciences. International Journal of Social Science Studies, 5(12), 44-49. https://doi.org/10.11114/ijsss.v5i12.2775

Serpa, S., Ferreira, C. M., Santos, A. I., \& Teixeira, R. (2018). Participatory action research in higher education training. International Journal of Social Science Studies, 6(6), 1. https://doi.org/10.11114/ijsss.v6i6.3286

Sousa, S. (2010). A 'comunidade académica' como um conceito errático [The 'academic community' as an erratic 
concept]. Sociologia. Revista do Departamento de Sociologia da FLUP, XX, 149-166.

Ustun, S., \& Gümüseli, A. I. (2017). Many lives of women rectors at Turkish universities. Journal of Education and Training Studies, 5(8), 123-131. https://doi.org/10.11114/jets.v5i8.2424

Vélot, C. (2016). Scientists and civil society must move together toward a new science. Frontiers in Public Health, 4(96), 1-3. https://doi.org/10.3389/fpubh.2016.00096

Williams, L., Nixon, S., Hennessy, C., Mahon, E., \& Adams, G. (2016). Inspiring to inspire: Developing teaching in higher education. Cogent Education, 3(1), 1-12. https://doi.org/10.1080/2331186X.2016.1154259

Wood, M., \& Su, F. (2017). What makes an excellent lecturer? Academics' perspectives on the discourse of 'teaching excellence' in higher education. Teaching in Higher Education, 22(4), 451-466. https://doi.org/10.1080/13562517.2017.1301911

Ziman, J. (1994). Prometheus bound: Science in a dynamic steady State. Cambridge: Cambridge University Press. https://doi.org/10.1017/CBO9780511585067

\section{Copyrights}

Copyright for this article is retained by the author(s), with first publication rights granted to the journal.

This is an open-access article distributed under the terms and conditions of the Creative Commons Attribution license which permits unrestricted use, distribution, and reproduction in any medium, provided the original work is properly cited. 